\title{
28 Research Square \\ Understanding the origin and evolution of magnetic organelles in bacteria
}

Wei Lin

Wensi Zhang

Greig A. Paterson

Qiyun Zhu

Xiang Zhao

Rob Knight

Dennis A. Bazylinski

Andrew P. Roberts

Yongxin Pan

\section{Video Byte}

Keywords: Magnetotactic bacteria, Magnetosome, Magnetotaxis, Prokaryotic organelle, Last bacterial common ancestor, Microbiome

Posted Date: November 13th, 2020

DOI: https://doi.org/10.21203/rs.3.rs-107500/v1

License: (c) (i) This work is licensed under a Creative Commons Attribution 4.0 International License. Read Full License 


\section{Abstract}

Membrane-bound organelles were once believed to be unique to the complex cellular structure of eukaryotes, but researchers are finding a growing number of exceptions among bacteria that includes the discovery of compass-like magnetosomes, chains of magnetic particles wrapped inside a lipid membrane that guide magnetotactic bacteria to food or filter out harmful chemicals. Understanding how magnetosomes first formed and evolved could provide clues to how other organelles made their way into bacteria and other prokaryotes. Researchers recently embarked on the most comprehensive metagenomic analysis of magnetotactic bacteria across various ecosystems. With 168 genomes reconstructed, their findings greatly expand the number of bacteria lineages associated with magnetosomes and magnetic navigation. An analysis of the core magnetosome proteins discovered strengthens the idea that magnetosomes have an ancient origin possibly dating back to the beginning of the bacterial domain of life. The study's findings could help researchers better understand the mechanisms of magnetosome formation and assist in the cultivation of previously uncultured magnetotactic bacteria. 